\title{
An Ayurvedic Approach to Alcoholism in Diabetics: Clinical Contrive
}

\author{
Suhas Kumar Shetty ${ }^{1 *}$, Savitha HP², Wasuki Upadyaya ${ }^{3}$ \\ 1Professor, ${ }^{2}$ Associate Professor, ${ }^{3}$ Research Associate \\ Dept of Manasa Roga, SDM College of Ayurveda \& Hospital, Hassan, India.
}

\begin{abstract}
Diabetes mellitus (DM) is a chronic, progressive metabolic disorder with several complications that affect virtually all the systems in the human body. The management of DM is multifactorial, taking into account other major modifiable risk factors, like obesity, physical inactivity, smoking, blood pressure, and dyslipidemia. A multidisciplinary team is essential to maximize the care of individuals with DM. Regular consumption of even moderate amounts of alcohol interferes with diabetic blood sugar control and increases the risk of Complications. Various Complementary and alternative systems (CAM) have been effective and beneficial in management of life style disorders like DM with alcoholism. Ayurveda remains one of the most ancient and yet living traditions practised widely in India and has a sound philosophical and experiential basis. The planning of an effective adequate management of alcoholism in DM in Ayurveda with the aid of Ahara (Diet), Vihara (Life style modification), Achara (code of conduct) and Aushadhi (medicines) depends upon the strength of the disease (Roga) and the stamina of the patient (Rogi). Various dietary and
\end{abstract}

\section{INTRODUCTION}

Diabetes mellitus (DM) is a chronic, progressive metabolic disorder characterized by hyperglycemia with long-term microvascular (retinopathy, nephropathy, and neuropathy) and vascular (cardiovascular) complications. Alcohol consumption by diabetics can worsen blood sugar control. For example, long-term alcohol use in well-nourished diabetics can result in excessive blood sugar levels. Conversely, long-term alcohol ingestion in diabetics who are not adequately nourished can lead to dangerously low blood sugar levels ${ }^{1}$.

Regular consumption of even moderate amounts of alcohol (i.e., two to four drinks per day) interferes with diabetic blood sugar control and increases the risk of impotence, peripheral neuropathy, nephropathy and possibly even retinopathy. Diabetics should avoid heavy drinking (i.e., more than 10 to 12 drinks per day) absolutely, because it causes ketoacidosis and hypertriglyceridemia².

Alcohol consumption leads to altered lipid metabolism ie increased triglycerides level, hampered sexual performance, impotency, reduction in drug compliance, increased risk of microvascular - vascular complications etc. Hence early \& holistic management of alcoholism in diabetics can be an important factor for maintaining blood sugar level, improving quality of life and reducing incidence of complications ${ }^{2}$. lifestyle modifications with palliative and detoxifying therapies are advised for holistic management of DM with alcoholism in Ayurveda.

Key words: Diabetes mellitus, Alcoholism, Ayurveda, holistic.

\section{*Correspondence to:}

Dr Suhas Kumar Shetty, Professor, Dept of Manasa Roga, SDM College of Ayurveda \& Hospital, Hassan, India.

Email ID: drsuhasshetty@sdmcahhassan.org

Article History:
Received: 31-03-2016, Revised: 02-04-2016, Accepted: 31-05-2016
\begin{tabular}{|l|c|}
\hline \multicolumn{2}{|c|}{ Access this article online } \\
\hline $\begin{array}{l}\text { Website: } \\
\text { www.ijmrp.com }\end{array}$ & Quick Response code \\
\hline $\begin{array}{l}\text { DOI: } \\
\text { 10.21276/ijmrp.2016.2.3.044 }\end{array}$ & \\
\hline
\end{tabular}

Ayurveda (Traditional Indian health care system) understands diabetes mellitus under Madhumeha. As per pathogenesis, Madhumeha is divided into 2 types - Avaranaja Madhumeha (Predominantly Type 2 DM) and Dhatu Kshayaja Madhumeha (Type $1 \mathrm{DM})^{3}$. Excessive consumption of Madya (Alcohol) can interfere with blood sugar control in both types.

\section{DESCRIPTION \& DISCUSSION}

A comprehensive assessment \& management is required to treat alcoholism in diabetics through Ayurveda. A thorough evaluation of cause of starting alcohol drinking, type of alcohol, patterns \& behavior in terms of effect of alcohol on Dosha (Basic humours), Dhatu (Tissue), Srotas (Channels) and clinical symptoms need to be done ${ }^{4}$. The planning of an effective adequate management of disorder of alcohol use in Ayurveda with the aid of Ahara (Diet), Vihara (Life style modification), Achara (code of conduct) and Aushadhi (medicines) depends upon the strength of the disease and the stamina of the patient. For example, in cases of chronic patients with sufficient stamina, Panchakarma specially Vamana ${ }^{5,6}$ (herbally induced therapeutic emesis) is the suitable and appropriate measure, whereas in acute intoxicated patients with diminished stamina, palliative treatment (Shamana Chikitsa) \& diet is the appropriate management ${ }^{7}$. 


\section{Ahara (Diet)}

Considering diabetes and alcoholism, one may advise diet consisting of milk, buttermilk, milk with rice, green leafy vegetables, gooseberry, ash gourd, tender coconut, sugar cane juice, wheat, barley etc. It is advised to eat regularly and when one is hungry. Choose less refined high sugar foods \& drinks, cereals, pulses, fruits $\&$ vegetables. One need to avoid spicy food, salty food, oily food, non-veg food specially pork \& red meat ${ }^{8,9}$.

\section{Vihara (Life style)}

Life style modification like Sadvritta (Behavioral \& moral codes), exercise etc can help improve one's self esteem, increase endorphins, reduce pain, induce good sleep etc. Yoga Asana like Tadasana, Trikonasana, Halasana, Noukasana, Vajrasana, Bhujangasana, Paschimothansana, Shashankasana, Sarvangasana \& Pranayama like Ujjayai, Bhastrika \& Yognidra are beneficial in alcoholism \& diabetes ${ }^{10}$. Following therapies are advised based on Kosha11:

\begin{tabular}{ll}
\hline Kosha & Therapies \\
\hline Annamaya (Physical body) & Asana, Kriya \\
Pranamaya (Energy body) & Kriya, Pranayama \\
Manomaya (Mental body) & Meditation \\
Vijnanamaya (Intellectual & Bhajan, Jnana \& Karma \\
body) & Yoga \\
Anandamaya (Blissful body) & Higher level practices \\
\hline
\end{tabular}

\section{Achara (Psychological measures)}

Satvavajaya Chikitsa (Ayurvedic Psychotherapy) is important in the management of alcoholism \& Diabetes. Satvavajaya refers to psycho-physical exercises or techniques, designed to achieve a regulation or balance/ equilibrium over the human psyche, in dealing with the environmental stressors (Indriyartha) and emotional stressors (Manoartha). Jnana - Knowledge of the self, Vijnana - Cognitive Behavioral Therapy, Dhairya - Motivational Enhancement Therapy, Smrti - Distraction, Samadhi - Yoga Techniques are to be adopted with proper care. Mano Nigraha Mind controlling methods, Ashwasanadi - Reconciliatory measures, Mano Kshobhana - Psycho-Physical shocks, Samadhi - Equanimity are proven beneficial in alcoholism \& diabetes ${ }^{12}$.

\section{Aushadhi (Therapies \& medicines)}

Treatment of alcoholism in Ayurveda can be planned considering whether the patient is in state of intoxication or withdrawal state or chronic state. In the acute state \& in patients who are fit, SadyoVamana (immediate emesis) can be planned with Lavanajala (salt water) and Yastimadhu Phanta (licorice infusion). Tarpanadi Samsarjana (nourishing recuperative diet) like Laja (puffed rice), Saktu (flour of any dry fried grain), Yusha (pulse soup) etc. should be advised. Virechana (herbally induced therapeutic purgation) is contra-indicated in acute phase, especially in those having less strength or are emaciated by alcohol use, because the purpose of Shodhana in acute phase is to reduce the absorption of alcohol by the body whereas Virechana acts only after the absorption. Palliative \& nourishing diet and medicines like Kharjura (date), Dadima (pomegranate), Draksha (grape) etc can be given ${ }^{13}$.

External application therapies like Abhyanga (oil massage), Shirodhara (streamline pouring of medicated oil/buttermilk/decoction on forehead), Shiro Lepa (herbal paste application on head) and Shiro Pichu (application of oil/paste over scalp) using Ksheerabala taila, Brahmi Taila, Himasagar Taila etc may be advised in the withdrawal state for the period of 5 to 7 days or till the cessation of withdrawal symptoms like headache, nausea, tremors, disturbed sleep, loss of appetite etc. Though Asava and Arista (Ayurvedic alcoholic medicinal preparations) are the drugs of choice in the Ayurvedic management of alcoholic disorders, one need to be careful in its usage in diabetics. One may use Shrikandasava ${ }^{14}$, Draksharista ${ }^{15}$, Parthadyarista ${ }^{16}$ etc in moderation in controlled diabetics but avoid it in uncontrolled diabetics. Single drugs like Ashvagandha (Withania somnifera Dunal.), Brahmi (Bacopa monnieri Linn.), Jatamamsi (Nardostachys jatamansi DC.), Shankapushpi (Convolvulus pluricaulis Choisy), Bringaraja (Eclipta alba Hassk.), Kushmanda (Benincasa hispida Thunb.), Mandookaparni (Centella asiatica Linn.), Guduchi (Tinospora cordifolia Willd.) etc can be used based on the clinical symptoms and the Dosha involved.

\section{CONCLUSION}

Holistic management of alcoholism in diabetics needs proper clinical evaluation and assessment of Dosha \& Srotas involved. Alcohol abstinence along with appropriately beneficial Ahara, Vihara, Achara and Aushadhi can be advised for the early management, based on the severity of alcoholism in diabetics, thereby reducing the risk of long term complications.

\section{REFERENCES}

1. Kaplan, Sadock: Comprehensive textbook of psychiatry, Lippincott Williams \& Wilkins publication, 8th edition, 2005, 11.2 Alcohol Related Disorders, page no - 1168.

2. Nicholas V. Emanuele, M.D., Terrence F. Swade, M.D., Mary Ann Emanuele, M.D. Consequences of Alcohol Use in Diabetics, Alcohol Health \& Research World; Vol. 22, No. 3, 1998, p 211 - 19

3. Ashok Kumar Panda, Comprehensive Ayurveda care in Type 2 Diabetes, Journal of traditional medicine and clinical naturopathy, Jan 2014, DOI - 10.4172/2167-1206.1000e111

4. Shetty SK, Savitha HP, Narayana Prakash B. Critical Review on Role of Panchakarma in Madatyaya (Alcoholic Disorders). Journal of Ayurveda and Holistic Medicine. 2013;1(1):12-16.

5. Sheetal L Sadalagi, Narayana Prakash B, Suhas Kumar Shetty, Effect of Vamana and Ashtanga Lavana in the management of Madatyaya, AYU-Vol. 30, no. 4 (October- December) 2009, pp. 463468

6. Suhas Kumar Shetty, Savitha H P, Narayana Prakash B Effectiveness Of Vamana (Therapeutic Emesis) And Astangalavana (Ayurvedic Herbo Mineral Compound) On Alcohol Withdrawal Syndrome; International Ayurvedic Medical Journal, Volume 3; Issue 7; July- 2015: page $2051-59$

7. Sharma R, Amin H, Ruknuddin G, Prajapati PK. Efficacy of Ayurvedic remedies in type 2 diabetes: A review through works done at Gujarat Ayurveda University, Jamnagar. J Med Nutr Nurtraceut 2015; 4:63-9

8. Silvio E. Inzucchi et al, Management of Hyperglycemia in Type 2 Diabetes: A Patient-Centered Approach; Diabetes Care. 2012 Jun; 35(6): 1364-1379.

9. Guddoye $G$, Vyas $M$, Role of diet and lifestyle in the management of Madhumeha (Diabetes Mellitus), Ayu 2013 Apr-Jun; 34(2): 167-173 10. Kim E Innes, Terry Kit Selfe. Yoga for Adults with Type 2 Diabetes: A systematic review of controlled trails. Journal of Diabetes Research; Vol 2016, Article ID 6979370, 23 pages 
11. Nagendra H R. Integrated Yoga Therapy for mental illness, Indian J Psychiatry. 2013 Jul; 55(Suppl 3) S337-S339

12. Behere PB, Das A, Yadav R, Behere AP. Ayurvedic concepts related psychotherapy. Indian J Psychiatry 2013;55, Suppl S2: 310-4

13. Agnivesha: Charaka Samhitha with the 'Ayurveda deepika' commentary by Chakrapanidatta edited by Trivikrimatmajena Yadav Sharma, Choukambha Sanskrit Sansthana. Varanasi, Publications. 1994 year edition. Chikitsa stana 24/101-106.Page no.587.

14. Siddhinandan Mishra (Editor) Bhaishajya Ratnavali of Raviraj Govinda Das Sen; Vol 1: Varanasi, Chaukhambha Ayurvijnana Granthamala , Madatyaya Chikitsa - 22/29-33, page 497

15. Siddhinandan Mishra (Editor) Bhaishajya Ratnavali of Raviraj Govinda Das Sen; Vol 1: Varanasi, Chaukhambha Ayurvijnana Granthamala, 14/73-76, page 412-13

16. Siddhinandan Mishra (Editor) Bhaishajya Ratnavali of Raviraj Govinda Das Sen; Vol 1: Varanasi, Chaukhambha Ayurvijnana Granthamala, 33/73-75, page 673

\section{Source of Support: Nil.}

Conflict of Interest: None Declared.

Copyright: (c) the author(s) and publisher. IJMRP is an official publication of Ibn Sina Academy of Medieval Medicine \& Sciences, registered in 2001 under Indian Trusts Act, 1882.

This is an open access article distributed under the terms of the Creative Commons Attribution Non-commercial License, which permits unrestricted non-commercial use, distribution, and reproduction in any medium, provided the original work is properly cited.

Cite this article as: Suhas Kumar Shetty, Savitha HP, Wasuki Upadyaya. An Ayurvedic Approach to Alcoholism in Diabetics: Clinical Contrive. Int J Med Res Prof. 2016; 2(3): 201-03. 